\title{
7-Aminoactinomycin D
}

National Cancer Institute

\section{Source}

National Cancer Institute. 7-Aminoactinomycin D. NCI Thesaurus. Code C72904.

A fluorescent nucleic acid dye which selectively binds GC sequences in double-stranded

DNA. It has a molecular weight of 1270.5, an absorbance maximun at $546 \mathrm{~nm}$, and emission maximum at $647 \mathrm{~nm}$. It is commonly used to discriminate viable from nonviable cells. 